\title{
Pengembangan E-Modul Berbasis Learning Content Development System Pokok Bahasan Pola Bilangan SMP
}

\author{
Iin Rahmatul Ula ${ }^{*}$, Abi Fadila² \\ 1 Prestasi, Perumahan Cendana Indah. Jalan Pulau Bangka, Sukabumi, Bandar Lampung \\ 35122, Indonesia. \\ 2Universitas Islam Negeri Raden Intan Lampung, JalanEndro Suratmin, Sukarame, Bandar Lampung \\ 35133, Indonesia \\ *Corresponding Author. E-mail: iinrahmatulula@gmail.com
}

Received : 28-05-2018; Revised : 30-05-2018; Accepted : 31-05-2018

\begin{abstract}
Abstrak
Penelitian ini bertujuan untuk menghasilkan bahan ajar berupa modul elektronik berbasis learning content development system pada materi pola bilangan. Metode penelitian ini adalah Research and Development (R\&D) berdasarkan model ADDIE. Penilaian ahli materi terhadap media pembelajaran ini termasuk dalam kategori "Valid" dengan nilai rata-rata sebesar 3,46. Penilaian ahli media terhadap e-modul ini termasuk dalam kategori "Valid" dengan nilai rata-rata sebesar 3,66. Penilaian ahli bahasa terhadap media ini termasuk dalam kategori "Valid" dengan nilai rata-rata sebesar 3,6. Pada uji coba skala kecil yang diikuti oleh 10 peserta didik kelas VII memperoleh skor rata-rata yaitu 3,65 berdasarkan hasil dari angket respon yang telah diisi oleh peserta didik, hasil ini menempatkan e-modul pada kriteria "Sangat Menarik". Pada uji coba lapangan skala besar yang diikuti oleh 30 peserta didik skor rata-rata kemenarikan yang diperoleh yaitu 3,55 pada kriteria "Sangat menarik".
\end{abstract}

Kata kunci: Pengembangan E-Modul Berbasis Learning Content Development System , Pola Bilangan

\begin{abstract}
This study aims to produce instructional materials in the form of electronic module based learning content development system on the matter of pattern number. This research method is Research and Development ( $R \& D$ ) based on ADDIE model. Assessment of material experts on the learning media is included in the category of "Valid" with an average value of 3.46. The media expert's assessment of this e-module is included in the "Valid" category with an average grade of 3.66. The linguist's assessment of this medium is included in the "Valid" category with an average grade of 3.6. In a small-scale trial followed by 10 students of class VII obtained an average score of 3.65 based on the results of a response questionnaire that has been filled by the learner, this result puts the e-module on the criteria "Very Interesting". In large-scale field trials followed by 30 students, the average score of attractiveness obtained was 3.55 on the criteria "Very interesting".

Keywords: Development of E-Module Based on Learning Content Development System, Pattern of Numbers
\end{abstract}

\section{PENDAHULUAN}

Pendidikan membuat manusia berusaha mengembangkan dirinya sehingga mampu menghadapi setiap perubahan yang terjadi akibat adanya kemajuan ilmu pengetahuan dan

teknologi. Mata pelajaran yang sangat berperan terhadap perkembangan zaman adalah mata pelajaran matematika karena matematika menjadi penemu dan perkembangan ilmu yang lain (Rizki 
Wahyu Yunian Putra, 2015). Proses pendidikan tidak dapat dipisahkan dari proses pembelajaran. Hasil wawancara yang dilakukan oleh peneliti kepada pendidik tanggal 23 Oktober 2017, bahwa pembelajaran matematika di SMP Negeri 24 Bandar Lampung merupakan kegiatan yang dilaksanakan oleh pendidik, dengan mengenalkan subjek, memberi satu dua contoh, lalu menanyakan satu atau dua pertanyaan, dan pada umumnya peserta didik yang biasanya mendengarkan secara pasif diminta untuk menjadi aktif dengan mulai mengerjakan latihan yang diambil dari buku. Selanjutnya aktivitas serupa dilakukan untuk pertemuan-pertemuan berikutnya. Aktivitas yang menjadi rutinitas dimana pendidik menerangkan materi dan murid menerima materi (Nurwani, Rizki Wahyu Yunian Putra, Fredi Ganda Putra, 2017). Selama proses pembelajaran berlangsung, tentu saja peserta didik membutuhkan bahan ajar yang menarik sebagai alat yang dijadikan sebagai sumber informasi belajarnya(Tania and Susilowibowo, 2017), Sehingga diperlukan pengembangan bahan ajar dengan berinovasi yang menarik agar peserta didik berantusias dan senang untuk belajar.

Hasil dari penelitian sebelumnya mengembangkan bahan ajar e-modul sebagai pendukung pembelajaran kurikulum 2013(Susilowibowo, 2017). Selain itu penelitian lainnya mengembangkan bahan ajar modul berbasis literasi sains model addie(Tegeh and Kirna, 2013). Kemudian penelitian lainnya mengembangkan e-modul dengan model guided note taking (Nurmawati, Ismartoyo, and Prayitno, 2015). Penelitian berikutnya mengembangkan modul matematika dengan strategi problem solving untuk mengukur tingkat kemampuan berpikir kreatif matematis siswa (Anggoro, 2015). Kemudian penelitian selanjutnya mengembangkan pengembangan modul pembelajaran matematika bermuatan emotion quotient (Fatikhah and Izzati, 2015). Penelitian selanjutnya mengembangkan e-modul berorientasi pemecahan masalah untuk meningkatkan keterampilan berfikir kritis mahasiswa(Suarsana and Mahayukti, 2013). Selain itu penelitian lainnya mengembangkan modul virtual multimedia flipbook dasar teknik digital (Sugianto et al, 2013). Penelitian lainnya mengembangkan modul interaktif menggunakan learning content development system pada materi listrik dinamis (Deny Kurniawan, Agus Suyatna, 2014). Dapat disimpulkan dari pembahasan diatas bahwa dalam penelitian ini e-modul dapat dikembangkan dengan berbagai inovasi sebagai bahan ajar untuk peserta didik.

Berdasarkan penelitian sebelumnya yang telah dipaparkan di atas, maka dalam penelitian ini peneliti tertarik melakukan sebuah penelitian yaitu mengembangkan e-modul berbasis learning content development system pada materi pola bilangan. Microsoft LCDS merupakan perangkat lunak gratis dari microsoft yang memungkinkan komunitas microsoft learning untuk mempublikasikan program e-learning dengan mengisi formulir LCDS yang mudah digunakan penggunanya yang menghasilkan konten yang sangat disesuaikan dengan kualitas tinggi dan interaktif yang berisi kuis, penilaian, animasi, demo, dan multimedia lainnya(Aremu and Efuwape, 2013).

Penelitian ini akan berbeda dengan penelitian sebelumnya dimana penelitian ini bukan hanya mengembangkan dengan software LCDS, e-modul ini juga kombinasi dengan software I-Spiring. Software I- 
Spiring melengkapi pada bagian evaluasi, dimana peserta didik tidak diperlukan menggunakan buku tulis dalam pengerjaan soal latihan, karena soal latihan sudah menyatu dalam e-modul serta skor otomatis akan muncul ketika peserta didik selesai mengerjakan soal latihan tersebut, sehingga peserta didik bisa mengetahui secara langsung akan sejauh mana dirinya memahami materi yang sudah dipelajari.

\section{METODE}

Metode penelitian ini adalah Research and Development (R\&D) berdasarkan model ADDIE. Fungsi dari model ADDIE adalah menjadi pedoman dalam membangun perangkat dan infrastruktur program pembelajaran yang efektif, dinamis dan dan mendukung kinerja pembelajaran itu sendiri. Model ini terdiri dari lima tahapan, yaitu Analysis,Design, Development, Implementation or Delivery, and Evaluation. Model ini dikembangkan oleh Dick dan Carry (Mulyatiningsih, 2012).

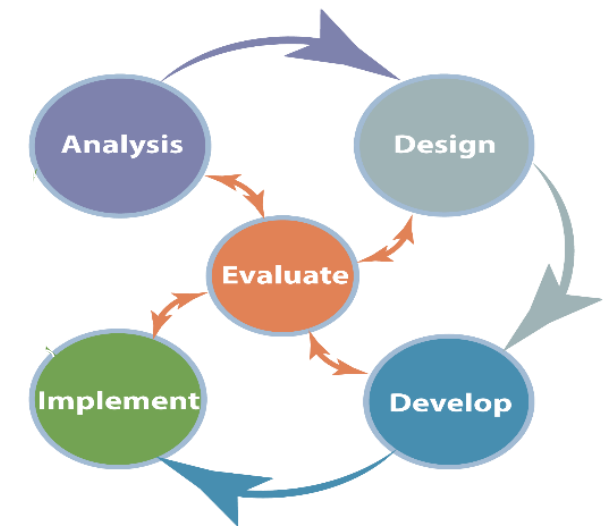

Gambar 1. Prosedur Pengembangan ADDIE

Data yang dikumpulkan pada penelitian ini adalah: (1) Data keutuhan awal penelitian yang diperoleh dari hasil angket peserta didik dan wawancara pendidik di SMP Negeri 24 Bandar Lampung, (2) Data hasil validasi ahli berupa penilaian terhadap e-modul berbasis LCDS pokok bahasan pola bilangan yang ditujukan pada sejumlah dosen pakar untuk melakukan validasi materi, bahasa, dan media. (3) Data respon peserta didik sehingga mendapatkan kelayakan e-modul. Instrumen dalam penelitian ini adalah lembar wawancara, lembar angket, lembar validasi, lembar respon peserta didik terhadap e-modul yang dikembangkan.

Analisis data untuk lembar validasi ahli dan respon peserta didik berbentuk skala tingkat. Skala pengukuran dengan tipe ini akan didapat jawaban dengan tegas, yaitu data tersebut diberi simbol angka : sangat layak 4, layak 3, kurang layak 2, tidak layak 1. Data yang terkumpul tersebut, selanjutnya dianalisis dengan langkah-langkah sebagai berikut :

a. Menghitung presentase dari setiap aspek dengan rumus:

$$
x_{i}=\frac{\sum S}{S_{\max }} \times 4
$$

Keterangan:

Smax : Skor maksimal

$\sum S:$ Jumlah skor

$X i$ : Nilai kelayakan angket tiap aspek

Hasil penilaian oleh validator tersebut diubah menjadi kualitatif dengan menggunakan kriteria penilaian pada skala model rating scale, yakni skala empat pada Tabel 1 di bawah ini.

Tabel 1 Skla Kemenarikan

\begin{tabular}{cc}
\hline Kategori & Skor \\
Sangat Menarik & 4 \\
Menarik & 3 \\
Kurang Menarik & 2 \\
Tidak Menarik & 1
\end{tabular}

b. Menghitung persentase rata-rata seluruh responden: 
Keterangan:

$$
\bar{x}=\frac{\sum_{i=1}^{n} x_{i}}{n}
$$

$\bar{x}$ : Rata-rata akhir

$x i$ : Nilai kelayakan angket tiap aspek

$n$ : Banyaknya pernyataan

1) Mengubah skor rata-rata yang diperoleh menjadi nilai kualitatif yang sesuai dengan kriteria penilaian pada Tabel 2.

Tabel 2 Skala Kelayakan Media Pembelajaran

\begin{tabular}{|c|c|c|}
\hline Rata-rata & $\begin{array}{c}\text { Kreteria } \\
\text { Kelayakan }\end{array}$ & Keterangan \\
\hline $3,21-4,00$ & $\begin{array}{c}\text { Valid/Layak } \\
\text { digunakan }\end{array}$ & (Tidak Revisi) \\
\hline $2,51-3,25$ & $\begin{array}{c}\text { Cukup } \\
\text { Valid/Layak } \\
\text { digunakan }\end{array}$ & $\begin{array}{c}\text { (Revisi } \\
\text { Sebagian) }\end{array}$ \\
\hline $1,76-2,50$ & $\begin{array}{l}\text { Kurang } \\
\text { Valid/Layak } \\
\text { digunakan }\end{array}$ & $\begin{array}{c}\text { (Revisi } \\
\text { sebagian dan } \\
\text { pengujian } \\
\text { ulang materi) }\end{array}$ \\
\hline $1,00-1,75$ & $\begin{array}{c}\text { Tidak } \\
\text { Valid/Layak } \\
\text { digunakan }\end{array}$ & (Revisi total) \\
\hline
\end{tabular}

Menentukan nilai keseluruhan dari penggunaan software LCDS ini dengan menghitung skor rata-rata seluruh kriteria penilaian, kemudian diubah menjadi nilai kualitatif sesuai dengan kriteria kategori dalam Tabel 2. Berdasarkan data tabel 2, maka produk pengembangan akan berakhir saat skor penilaian terhadap bahan ajar ini telah memenuhi syarat kelayakan dengan tingkat kesesuaian materi, kelayakan media, dan kualitas teknis pada e-modul berbasis LCDS pokok bahasan pola bilangan dikategori sangat menarik atau menarik.

\section{HASIL DAN PEMBAHASAN}

Hasil penelitian pertama adalah telah dikembangkannya bahan ajar berupa e-modul berbasis LCDS pokok bahasan pola bilangan. Bahan ajar ini berupa elektronik dalam bentuk modul dengan software LCDS dan dilengkapi dengan ilustrasi, contoh soal, video, dan uji kompetensi. Pengembangan bahan ajar ini disesuaikan dengan kurikulum 2013.

E-Modul materi pola bilangan ini terdiri atas komponen cover, petunjuk penggunaan modul, peta konsep, isi materi, soal evaluasi, kunci jawaban, dan daftar pustaka. Penyusunan modul memiliki peranan penting dalam pembelajaran. Peranan penting ini meliputi fungsi, tujuan, dan manfaat modul. Tidak hanya dijadikan sebagai bahan mandiri, modul juga dapat digunakan sebagai alat bantu pendidik atau pengganti pendidik, sebagai alat evaluasi hasil belajar peserta didik terhadap penguasaan materi yang tersedia dalam modul.

Berdasarkan permasalahan pada tahap analisis yang telah dikemukakan dalam hasil penelitian diketahui bahwa dalam proses pembelajaran di kelas pendidik masih menggunakan metode ceramah dan hanya memanfaatkan buku paket yang sudah disediakan di perpustakaan sekolah sebagai bahan ajar. Sementara rendahnya kemampuan peserta didik dalam memahami konsep bangun ruang.

Setelah tahap analisis, tahap selanjutnya adalah tahap design (perancangan). Pada tahap perancangan dilakukan penyusunan kerangka media, perancangan sistematika penyajian materi, dan perancangan instrumen. Perancangan sistematika penyajian materi disesuaikan dengan KI dan KD yang sudah ditentukan.

Selanjutnya tahap development. Tahap development merupakan tahap dalam pembuatan e-modul yang akan digunakan dalam proses belajar. Setelah produk selesai dibuat, kemudian 
dilakukan evaluasi oleh para ahli dan praktisi pendidikan yang disebut dengan validasi. Tujuannya untuk memperoleh masukan-masukan guna perbaikan $e$ modul yang dikembangkan.

Masukan dari para ahli dan praktisi pendidikan disunting sebagai acuan revisi, selain itu juga pengisian angket validasi akan menentukan kelayakan e-modul untuk dapat diujicobakan kepada peserta didik. Revisi ini dilakukan sebagai langkah membuat produk yang layak. Produk yang telah dikembangkan kemudian direvisi pada beberapa komponen yang harus diperbaiki dalam e-modul, seperti memasukan video ke dalam e-modul agar peserta didik tidak mudah bosan, mengubah background e-modul agar menjadi lebih menarik serta komponen lain yang harus diperbaiki.

Penilaian ahli materi terhadap media pembelajaran ini termasuk dalam kategori "Valid" dengan nilai rata-rata sebesar 3,46. Penilaian ahli media terhadap e-modul ini termasuk dalam kategori "Valid" dengan niali rata-rata sebesar 3,66. Penilaian ahli bahasa terhadap media ini termasuk dalam kategori "Valid" dengan nilai rata-rata sebesar 3,6.

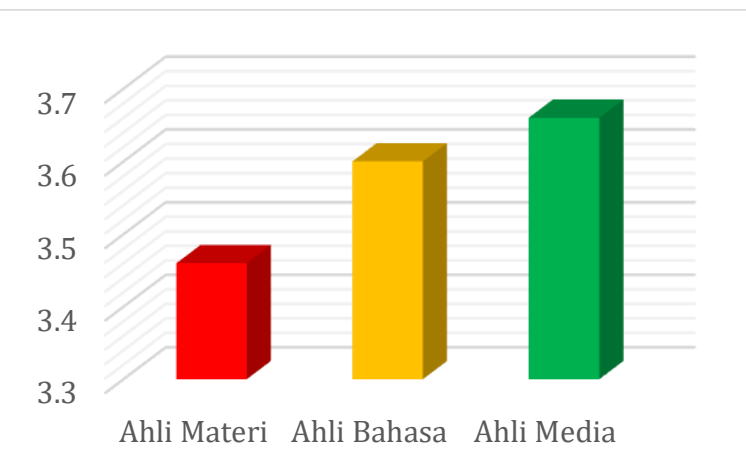

Gambar 2. Persentase penilaian Para Ahli

Setelah media direvisi dan dinyatakan Valid untuk diujicobakan, kemudian dilakukan ujicoba kepada peserta didik. Tahap ini disebut dengan tahap implementation. Hasil rata-rata kemenarikan yang diperoleh pada skala kecil yang diikuti oleh 10 peserta didik memperoleh skor rata-rata yaitu 3,65 berdasarkan hasil dari angket respon yang telah diisi oleh peserta didik, hasil ini menempatkan media pada kriteria "Sangat Menarik". Pada uji coba lapangan skala besar yang diikuti oleh 30 peserta didik skor rata-rata kemenarikan yang diperoleh yaitu 3,55 pada kriteria "Sangat menarik".

Tabel 3 Skala Uji Coba Kecil

\begin{tabular}{cccc}
\hline $\begin{array}{c}\text { Jumlah } \\
\text { Skor }\end{array}$ & $\begin{array}{c}\text { Skor } \\
\text { Kelayakan }\end{array}$ & $\begin{array}{c}\text { Skor } \\
\text { kelayakan } \\
\text { rata-rata }\end{array}$ & Kriteria \\
472 & 36,26 & 3,65 & $\begin{array}{c}\text { Sangat } \\
\text { Menarik }\end{array}$ \\
\hline
\end{tabular}

Tabel 4 Uji Coba Kelompok Besar

\begin{tabular}{cccc}
\hline $\begin{array}{c}\text { Jumlah } \\
\text { Skor }\end{array}$ & $\begin{array}{c}\text { Skor } \\
\text { Kelayakan }\end{array}$ & $\begin{array}{c}\text { Skor } \\
\text { Kelayakan } \\
\text { rata-rata }\end{array}$ & Kriteria \\
1.389 & 106,71 & 3,55 & $\begin{array}{c}\text { Sangat } \\
\text { Menarik }\end{array}$ \\
\hline
\end{tabular}

Berdasarkan hasil olah data angket respon peserta didik pada uji coba skala kecil dan uji lapangan skala besar, e-modul matematika yang dikembangkan dalam kriteria interpretasi kemenarikan sangat menarik sebagai sumber bahan belajar dan layak digunakan. Pemilihan aplikasi sebagai pendukung dalam pembuatan e-modul yang dikembangkan dikarenakan perkembangan teknologi, sehingga menyebabkan penggunaan bahan ajar yang paling tepat adalah modul elektronik. Modul elektronik dapat digunakan sebagai alat bantu mengajar karena media audio visual merupakan media yang memiliki unsur gerakan dan suara. Dapat disimpulkan bahwa hasil akhir pengembangan e-modul berbasis Learning Content Development System ini layak digunakan sebagai bahan ajar matematika pada materi pola bilangan.

Hal ini terbukti dalam penelitian sebelumnya yang mengembangkan modul interaktif menggunakan learning content 
development system pada materi listrik dinamis (Deny Kurniawan, 2014). Hasil uji eksternal memperlihatkan produk modul interaktif dinilai menarik, mudah digunakan, dan bermanfaat bagi siswa sebagai sumber belajar konsep listrik dinamis. Hal ini dapat dilihat dari skor kualitas ke- menarikan modul interaktif mencapai 3,14. Dari skor tersebut dapat kita ketahui bahwa produk modul dengan software LCDS dengan kreteria "Menarik".

Berbeda dengan penelitian sebelumnya, peneliti disini selain menggunakan software LCDS, peneliti juga mengkombinasi dengan software I-Spring. Keunggulan mengkombinasi dengan software I-Spring yaitu membuat lebih praktis pada bagian evaluasi, sebab peserta didik dapat mengerjakan evaluasi langsung di dalam $e$ modul serta berkesempatan memilih nomor yang mudah terlebih dahulu untuk dikerjakan. Skor dalam pengerjaan evaluasi dapat dilihat langsung oleh peserta didik, sehingga hasil dari angket uji lapangan sakala besar yang diikuti oleh 30 peserta didik dengan skor rata-rata kemenarikan yang diperoleh yaitu 3,55 pada kreteria "Sangat Menarik". Dapat kita simpulkan dari pembahasan di atas dengan mengembangkan e-modul berbasis LCDS menarik untuk peserta didik, namun akan lebih menarik ketika dikombinasi dengan software I-Spring.

\section{SIMPULAN DAN SARAN}

Berdasarkan teori dan didukung oleh hasil respon peserta didik serta mengaru pada perumusan maslah yang diuraikan, maka dapat disimpulkan bahwa e-modul berbasis LCDS yang dikombinasi dengan software I-Spring yaitu "Sangat menarik" dari perhitungan skor rata-rata pada uji coba skala kecil yaitu 3,65\% dan pada uji coba lapangan skala besar yang diikuti oleh 30 peserta didik skor rata-rata kemenarikan yang diperoleh yaitu 3,55 pada kriteria "Sangat menarik" dan dikatagorikan sangat layak untuk digunakan. LCDS ini dapat digunakan, baik secara mandiri maupun kelompok, dan dapat dioperasikan pada laptop ataupun komputer PC yang telah terinstal dengan aplikasi flash player dan microsoft silverlight untuk memudahkan pengoperasian. E-Modul yang dihasilkan LCDS akan lebih menarik apabila di tunjang oleh aplikasi lain seperti microsoft power point, photoshop, corel draw, dan aplikasi lain yang dapat menampilkan text dan gambar yang kemudian digunakan sebagai bahan dalam pembuatan modul interaktif pada LCDS.

Pendidik diharapkan dapat memanfaatkan multimedia sebagai media untuk menyampaikan materi sehingga selain mempermudah dan membantu pendidik, multimedia yang dapat bersifat interaktif juga dapat membuat peserta didik lebih merasa senang, menarik perhatian, dan tidak membuat peserta didik jenuh dalam proses pembelajaran sehingga tercipta suasana yang aktif dalam pembelajaran. Harapannya untuk peneliti selanjutnya dapat mengembangkan e-modul matematika dengan menggunakan LCDS ini dengan desain yang berbeda dan dipadukan dengan software pendukung lainnya yang berbeda dengan yang sudah ada.

\section{DAFTAR PUSTAKA}

Anggoro, B. S. (2015). Pengembangan Modul Matematika Dengan Strategi Problem Solvin Guntuk Mengukur Tingkat Kemampuan Berpikir Kreatif Matematis Siswa. Al-Jabar: Jurnal Pendidikan Matematika, 6(2), 121130.

Aremu, A., \& Efuwape, B. M. (2013). A Microsoft Learning Content Development System ( LCDS ) Based Learning Package for Electrical and Electronics Technology-Issues on Acceptability and Usability in Nigeria. 
American Journal of Research, 1(2), 41-48.

https://doi.org/10.12691/education1-2-2

Deny Kurniawan, Agus Suyatna, W. S. (2014). Pengembangan Modul Interaktif Menggunakan Learning Content Development System pada Materi Listrik Dinamis. Jurnal Pembelajaran Fisika, 3(1), 1-10.

Fatikhah, I., \& Izzati, I. (2015). Pengembangan Modul Pembelajaran Matematika Bermuatan Emotion Quotient Pada Pokok Bahasan Himpunan. Eduma, 4(2), 46-61.

Nurmawati, Ismartoyo, \& Prayitno, E. (2015). Pengembangan E-modul Dengan Model Guided Note Taking ( GNT ) Pada Mata Kuliah Pendidikan Matematika II Program S1 PGSD BI di Pokjar. Jurnal Aksioma, 6(1), 82.

Nurwani, Rizki Wahyu Yunian Putra, Fredi Ganda Putra, N. W. P. (2017). Pengembangan Desain Didaktis Bahan Ajar Materi Pemfaktoran Bentuk Aljabar pada Pembelajaran Matematika SMP. Numerical, 1(2), 193-206.

Rizki Wahyu Yunian Putra, R. A. (2015). Pengembangan Bahan Ajar Materi Trigonometri Berbantuan Software iMindMap pada Siswa SMA Rizki. AlJabar: Jurnal Pendidikan Matematika, $7(1)$, 1-5. https://doi.org/10.19616/j.cnki.bmj. 2016.08.007

Suarsana, M., \& Mahayukti, G. A. (2013). Pengembangan E-Modul Berorientasi Pemecahan Masalah Untuk Meningkatkan Keterampilan Berfikir Kritis Mahasiswa. Jurnal Pendidikan Matematika, FMIPA, Universitas Pendidikan Ganesha, 2(2), 264-275. https://doi.org/10.23887/jpiundiksha.v2i2.2171

Sugianto, D., Abdullah, A. G., Elvyanti, S., \&
Muladi, Y. (2013). Modul virtual: Multimedia flipbook dasar teknik digital. Invotec, IX(2), 101-116.

Tania, L., \& Susilowibowo, J. (2017). Pengembangan Bahan Ajar E-Modul sebagai Pendukung Pembelajaran Kurikuum 2013 pada Materi Ayat Jurnal Penyesuain Perusahaan Jasa SIswa Kelas X Akutansi SMK Negeri 1 Surabaya. Unesa, 1-9.

Tegeh, I. M., \& Kirna, I. M. (2013). Pengembangan Bahan Ajar Metode Penelitian Pendidikan dengan Addie Model. Jurnal Ika, 1(1), 12-26. 